\title{
Observing Climate Change Impacts on European Forests: What Works and What Does Not in Ongoing Long-Term Monitoring Networks
}

\author{
Filippo Bussotti ${ }^{*}$ and Martina Pollastrini ${ }^{\dagger}$ \\ Laboratory of Environmental and Applied Botany, Department of Agri-Food Productions and Environmental Science, \\ University of Florence, Florence, Italy
}

Keywords: crown dieback, crown defoliation, ICP forests, ecosystem functions, ecosystem services, national forest inventories, tree growth, tree mortality

\section{INTRODUCTION}

OPEN ACCESS

Edited by:

Massimiliano Tattini,

Consiglio Nazionale Delle Ricerche,

Italy

Reviewed by:

Lina Fusaro,

Sapienza University of Rome, Italy

*Correspondence:

Filippo Bussotti

filippo.bussotti@unifi.it

${ }^{\dagger}$ Present Address:

Martina Pollastrini,

Forestry Research Centre, Council for Agricultural Research and Economics,

Arezzo, Italy

Specialty section:

This article was submitted to Functional Plant Ecology,

a section of the journal Frontiers in Plant Science

Received: 13 February 2017 Accepted: 07 April 2017 Published: 25 April 2017

Citation:

Bussotti F and Pollastrini M (2017) Observing Climate Change Impacts on European Forests: What Works and What Does Not in Ongoing Long-Term Monitoring Networks.

Front. Plant Sci. 8:629.

doi: $10.3389 /$ fpls.2017.00629
Ecosystem services of forests are related to specific functions, such as growth, photosynthesis, regeneration, element cycling, soil formation, biodiversity holding, and so on. For this reason, a wide "bouquet" of attributes must be taken into consideration to evaluate the overall functionality of forests and their capacity to provide ecosystem services. These attributes may be considered "proxies" for specific relative ecosystem functions and services. The growth of trees and standing biomass is connected not only to the economic value of the forest (provisional services) but also to carbon sequestration and climate regulation (regulatory services). The overall canopy closure (i.e., leaf area index-LAI) can be considered a proxy for stand productivity (Gower et al., 1999) and stand transpiration (Yan et al., 2012), trees' capacity of uptake and filtration of air pollutants (Janhäll, 2015), and element cycling (Burton et al., 1991) as well for soil conservation through the regulation of heavy rain impacts (Park and Cameron, 2008). Parameters related to stand structure, species composition, and diversity may be considered indicative of the capacity of regeneration, to support game and wildlife and to host beneficial organisms against parasites. Some of these attributes are currently assessed in national forest inventories, and data can be useful to map the extension and level of related ecosystem services.

The ecosystem functions and services of forests can be affected by the harshening of environmental conditions. Climate change impacts on forests is the result of complex interactions between meteorological factors and soil conditions (Barbeta et al., 2015), pathological agents (Wermelinger et al., 2007), forest fires (Flannigan et al., 2000), and environmental pollution (De Vries et al., 2014). The action of these co-occurring factors contributes to tree mortality and the reduction of canopy cover, as well-changes in stand composition and diversity (Millar and Stephenson, 2015). These effects can be evaluated by comparing subsequent forest inventories; however, the long period of time elapsing between two successive surveys can make them scarcely applicable if our purposes are to detect and monitor in time and space the impacts of climate change on forest ecosystem structure, functionalities and services provided.

In Europe and North America are currently implemented programs for forest health assessment. The European ICP Forests program (www.icp-forests.net) consists of two networks of monitoring plots (extensive and intensive) where various monitoring activities are repeated at different temporal bases. These networks were designed to assess the effects of transboundary air pollution and atmospheric depositions (De Vries et al., 2014) and represent the most important tool to assess changes in forest ecosystems health condition at national and European scales. A change of perspective, from atmospheric pollution and deposition to multiple stress pressure related to 
climate change, suggests a revaluation of the overall structure of the surveys and of the indicators adopted to observe the impacts on forests. The aim of this study is to verify whether, and to what extent, the current European forest health monitoring program is suitable for assessing the impacts of new global environmental factors, and give suggestions to enhance its informative potential.

\section{IMPACTS AT TREE LEVEL: TREE GROWTH AND CROWN DEFOLIATION}

The overall impacts of environmental stress on trees can be summarized with their effects on growth. Tree growth is a key parameter for evaluate the ability of forests to mitigate climate change and provide ecosystem services (Bonan, 2008). Forest health, however, is commonly assessed by means of crown defoliation (Michel and Seidling, 2014). Defoliation is a visual estimate of the relative amount of foliage loss of the target tree compared with that of the reference standard tree. Crown defoliation has been assessed extensively since the 1980s, and the trends recorded are assumed to be correlated with the effects of environmental stress, such as air pollution and climate change (Van Leeuwen et al., 2000). Although no clear relationships were found between defoliation and ecological factors at European level, local studies evidenced the impacts of ozone pollution (Augustatis and Bytnerowicz, 2008); extreme drought and heat weaves (Carnicer et al., 2011) and fluctuating climatic conditions (Ferretti et al., 2014). Intuitively, defoliation may affect growth through the reduction of the photosynthetic surface, but different ecophysiological processes (e.g., better exploitation of sunlight from the foliage in the inner part of the crown, increase of photosynthetic efficiency in the remaining foliage) can compensate for the loss of leaves. Growth reduction has been verified only for the most defoliated pine species (Pinus sylvestris L.) in Spain (Sánchez-Salguero et al., 2012), Italy (Castagneri et al., 2015), and Lithuania (Augustatis and Bytnerowicz, 2008).

\section{CHANGES AND DYNAMISMS IN FORESTS SUBJECTED TO CLIMATE CHANGE}

According to Millar and Stephenson (2015), forest cover under climatic change undergoes a progressive dieback of the crown and mortality of trees. During the period of decline, a regeneration of trees of different species, or of different genotypes of the same species, will occur. The decline of canopies induced by climate change may trigger a vegetational dynamism, with a temporary success of the early-successional tree species. In a longer time span, the regeneration of a "definitive" (mature) tree cover is supposed to be ensured by more xerophytic species coming from proximal areas (e.g., from lower elevation). This new generation of trees is supposed to be better adapted to the environmental condition of the previous one. The functions and services of forests are assumed to decrease during the canopy-decline period, but they are likely to be restored when the "new forest" is well-established. The equilibrium of the forest, adapted to a new environment, implies probably a different level of ecosystem functions and services, with respect to that which is provided by forests before the action of disturbing factors. Adaptation to drier conditions determines slower growth rates, lower foliar mass, reduced regeneration rate, and so on. These processes are ongoing in some parts of Europe and can be observed, for example, in P. sylvestris stands in the Valais (Switzerland) and the Italian Western Alps, where Quercus pubescens Willd. is going to replace $P$. sylvestris in the driest conditions (Rigling et al., 2013). The changes in the forest structure and species composition are associated with several events and signals, among which the most significant, due to its consequences, is the drought-induced tree mortality (Allen et al., 2015) and insect attacks in trees weakened by drought (Wermelinger et al., 2007; Anderegg et al., 2015).

Large spatial-scale events of drought-induced tree mortality have been registered in Europe and North America (Anderegg et al., 2013). Tree death is generally preceded by a severe decline of the growth and the dieback of a large part of the crown (Sánchez-Salguero et al., 2012). Dobbertin and Brang (2001) probed that the adoption of "defoliation" improves models to predict the mortality of trees in national forest inventories. Substantial reduction of foliar mass is assumed reflect the loss of photosynthates and compromises carbon allocation and tree growth (Garcia-Forner et al., 2016). According to Grote et al. (2016), big trees are especially subjected to water shortage and more likely to die than small trees, but Ruiz-Benito et al. (2013) and Van Gunst et al. (2016) found that in a "competitive" environment, as far as water resources are concerned, small trees are more likely to die.

A different scenario suggests the persistence of the current tree species, but with changes in the forest structure (i.e., reduction of tree density) to withstand the reduction of water resources. The "local evolution," or adaptation, of dominant tree species is promoted by the selection of more adapted individuals, that are those bearing the most suitable genotypes (Savolainen et al., 2007). The local evolution of species as a result of climate change is achieved by taking advantage of the existing genetic variability in natural populations. Increasing interest is devoted to epigenetic acclimation processes (Barbeta et al., 2013) and the so-called memory effect (Crisp et al., 2016), which may be responsible for the progressive reduction of the negative effects of severe drought on tree physiology and survival (Liu et al., 2015).

Tree diversity enhances growth and stabilizes productivity at stand level and on individual trees (Jucker et al., 2014; Liang et al., 2016), and it is supposed to modify the impacts of stress factors through "plant-to-plant" interactions. Such interactions may be either negative (competition) or positive (facilitation). According to the "stress gradient" hypothesis (He and Bertness, 2014), positive interactions are more frequent than negative ones in the poorest sites, where resources are scarce.

\section{WHAT WORKS AND WHAT DOES NOT}

Changes in the health and physiological conditions of trees are assumed to provide insights for the prevision of changes 
in ecosystems and may represent an alarm signal to interpret the dynamics of acclimation and/or adaptation processes of forests in new environmental conditions. Moreover, responses at tree and stand levels are influenced by stand structure, tree species composition, genomic features and overall diversity. Therefore, adopting a holistic view in the interpretation of interactions between tree health and all the components and processes of the ecosystem is necessary and more realistic.

The greatest usefulness of the extensive forest monitoring network in Europe is its very existence, as well as the existence of expert groups of scientists and technicians at national and European levels and a set of consolidated methods and manuals that make the assessed parameters (i.e., defoliation) reliable and generally accepted. What it needs is the introduction of concepts and indicators suitable for evaluating the mechanisms and processes performed by trees to withstand new environmental challenges owing to climate change. This integration of the current forest monitoring approach implies a substantial improvement of the diagnostic capacity of tree health indicators, combining the traditional visual assessment with more effective morphological and physiological indicators (Bussotti and Pollastrini, 2015).

The data series of ICP Forests (Level I, Timmermann et al., 2016), available from'90 in the past century, suggest a substantial stability (or slightly increasing defoliation) of crown conditions at the European level of some of the most diffuse tree species ( $P$. sylvestris, Picea abies (L.) Karst., Fagus sylvatica L.), alongside a progressive worsening of crown conditions of Mediterranean species. Local events of mortality (Bussotti et al., 2014, 2015), with impact at the regional level, are scarcely captured in the current forest monitoring activities. Therefore, for management purposes, locally intensifying the network to capture the most critical tree species and/or ecological conditions may be useful. This result can be achieved by involving local communities, as well as appealing to the so-called citizen science (McKinley et al., 2017).

\section{CONCLUSIONS: WHAT WE CAN DO}

To make the current terrestrial surveys able to capture the changes in forest ecosystems due to climate change, we need to shift the focus from the conditions of individual trees to the demography of the community. Mortality (including small trees, suckers, and understory woody vegetation) and regeneration are therefore key parameters to predict and interpret changes in tree species composition, local evolution, and possible desertification processes. Before tree death physiological stress conditions occur. These changes in plant health status, can be effectively assessed by foliar parameters, such as carbon isotope composition (that is proxy of drought stress, (Farquhar et al., 1982), and of carbon sequestration strategies of plants), chlorophyll fluorescence analysis, as indicator of overall plant stress conditions (Bussotti et al., 2010), and leaf morphology parameters (e.g., SLA, that indicates photosynthetic acclimation and vulnerability to stress, Bussotti, 2008). Tree ring analysis, moreover, is highly desirable to explore tree growth responses in relation to resilience, mortality and foliage loss (Lloret et al., 2011). A first list of the actions needed to improve the informative potential of extensive monitoring surveys in forest ecosystems is provided in Table 1.

TABLE 1 | Summary of the main features of the current extensive terrestrial survey in Europe (ICP Forests, Level I), and proposed additions to make the survey more effective to capture the effects of climate change.

\begin{tabular}{|c|c|}
\hline Current surveys & Proposed surveys \\
\hline \multicolumn{2}{|l|}{ GENERAL OBJECTIVES } \\
\hline Tree-based survey & Stand (forest population/community)-based survey \\
\hline $\begin{array}{l}\text { To assess the conditions of trees in relation to air pollution, } \\
\text { atmospheric deposition, and other environmental stress }\end{array}$ & To assess the changes in the structure and species composition of forests under climate change \\
\hline \multicolumn{2}{|l|}{ SAMPLING DESIGN } \\
\hline Spatial distribution according to a regular grid & $\begin{array}{l}\text { Regular spatial distribution can be locally intensified to capture the most critical situations. Contribute c } \\
\text { local communities and citizens }\end{array}$ \\
\hline Assessment is done every year. & Assessment may be done at multi-year basis (e.g., every 3-5 years) \\
\hline \multicolumn{2}{|l|}{ INDICATORS } \\
\hline Mortality of trees with diameter at breast height $(\mathrm{DBH})>10 \mathrm{~cm}$ & Mortality of trees and woody vegetation, including suckers and understory \\
\hline $\begin{array}{l}\text { Crown conditions (defoliation and symptoms) of trees with } \\
\mathrm{DBH}>10 \mathrm{~cm}\end{array}$ & $\begin{array}{l}\text { Foliar analysis (Chlorophyll content and fluorescence, carbon isotope composition, leaf morphology) } \\
\text { combined with crown condition assessment }\end{array}$ \\
\hline \multirow[t]{3}{*}{ Measurement of DBH every 5 year } & $\begin{array}{l}\text { Measurement of DBH combined with tree ring analysis to assess responses and resilience to severe } \\
\text { weather events }\end{array}$ \\
\hline & Leaf Area Index evolution \\
\hline & Regeneration \\
\hline
\end{tabular}


Establishing close relationships and exchanges between different levels of intensity in monitoring programs is desirable. Intensive monitoring networks, observational comparative plots (Baeten et al., 2013; von Gadow et al., 2016) and experimental plots (ecosystem manipulation, Perry and Troelstrup, 1988) are relevant for the assessment and validation of the feasibility of the proxies to be extensively assessed and their ecological and physiological significance.

\section{AUTHOR CONTRIBUTIONS}

FB and MP contributed equally to the discussion of the topic.

\section{REFERENCES}

Allen, C. D., Breshears, D. D., and McDowell, N. G. (2015). On underestimation of global vulnerability to tree mortality and forest die-off from hotter drought in the Anthropocene. Ecosphere 6, 1-55. doi: 10.1890/es15-00203.1

Anderegg, W. R., Hicke, J. A., Fisher, R. A., Allen, C. D., Aukema, J., Bentz, B., et al. (2015). Tree mortality from drought, insects, and their interactions in a changing climate. New Phytol. 208, 674-683, doi: 10.1111/nph.13477

Anderegg, W. R. L., Kane, J. M., and Anderegg, L. D. L. (2013). Consequences of widespread tree mortality triggered by drought and temperature stress. Nat. Clim. Change 3, 30-36. doi: 10.1038/nclimate1635

Augustatis, A., and Bytnerowicz, A. (2008). Contribution of ambient ozone to Scots pine defoliation and reduced growth in the Central European forests: a Lithuanian case study. Environ. Pollut. 155, 436-445. doi: 10.1016/j.envpol.2008.01.042

Baeten, L., Verheyen, K., Wirth, C., Bruelheide, H., Bussotti, F., Finér, L., et al. (2013). A novel comparative research platform designed to determine the functional significance of tree species diversity in European forests. Perspect. Plant Ecol. Evol. Syst. 15, 281-291. doi: 10.1016/j.ppees.2013.07.002

Barbeta, A., Mejía-Chang, M., Ogaya, R., Voltas, J., Dawson, T. E., and Peñuelas, J. (2015). The combined effects of a long-term experimental drought and an extreme drought on the use of plant-water sources in a Mediterranean forest. Glob. Chang. Biol. 21, 1213-1225. doi: 10.1111/gcb.12785

Barbeta, A., Ogaya, R., and Penuelas, J. (2013). Dampening effects of long-term experimental drought on growth and mortality rates of a Holm oak forest. Glob. Chang. Biol. 19, 3133-3144. doi: 10.1111/gcb.12269

Bonan, G. B. (2008). Forests and climate change: forcings, feedbacks, and the climate benefits of forests. Science 320, 1444-1449. doi: 10.1126/science.1155121

Burton, A. J., Pregitzer, K. S., and Reed, D. D. (1991). Leaf area and foliar biomass relationships in Northern hardwood forests located along an $800 \mathrm{~km}$ acid deposition gradient. Forest Sci. 37, 1041-1059.

Bussotti, F. (2008). Functional leaf traits, plant communities and acclimation processes in relation to oxidative stress in trees: a critical overview. Glob. Chang. Biol. 14, 2727-2739, doi: 10.1111/j.1365-2486.2008.01677.x

Bussotti, F., and Pollastrini, M. (2015). Evaluation of leaf features in forest trees: methods, techniques, obtainable information and limits. Ecol. Ind. 52, 219-230. doi: 10.1016/j.ecolind.2014.12.010

Bussotti, F., Desotgiu, R., Pollastrini, M., and Cascio, C. (2010). The JIP test: a tool to screen the capacity of plant adaptation to climate change. Scand. J. For. Res. 25, 43-50. doi: 10.1080/02827581.2010.485777

Bussotti, F., Ferrini, F., Pollastrini, M., and Fini, A. (2014). The challenge of Mediterranean sclerophyllous vegetation under climate change: from acclimation to adaptation. Environ. Exp. Bot. 103, 80-98. doi: 10.1016/j.envexpbot.2013.09.013

Bussotti, F., Pollastrini, M., Holland, V., and Brüggemann, W. (2015). Functional traits and adaptive capacity of European forests to climate change. Environ. Exp. Bot. 111, 91-113. doi: 10.1016/j.envexpbot.2014.11.006

Carnicer, J., Coll, M., Ninyerola, M., Pons, X., Sánchez, G., and Peñuelas, J. (2011). Widespread crown condition decline, food web disruption, and amplified tree mortality with increased climate change-type drought. Proc. Natl. Acad. Sci. U.S.A. 108, 1474-1478. doi: 10.1073/pnas.1010070108

Castagneri, D., Bottero, A., Motta, R., and Vacchiano, G. (2015). Repeated spring precipitation shortage alters individual growth patterns in Scots pine forests in the Western Alps. Trees 29, 1699-1712. doi: 10.1007/s00468-015-1250-z

Crisp, P. A., Ganguly, D., Eichten, S. R., Borevitz, J. O., and Pogson, B. J. (2016). Reconsidering plant memory: intersections between stress recovery, RNA turnover, and epigenetics. Sci. Adv. 2:e1501340. doi: 10.1126/sciadv.1501340
De Vries, W., Dobbertin, M. H., Solberg, S., van Dobben, H. F., and Schaub, M. (2014). Impacts of acid deposition ozone exposure and weather conditions in Europe: an overview. Plant Soil 380, 1-45. doi: 10.1007/s11104-014-2056-2

Dobbertin, M., and Brang, P. (2001). Crown defoliation improves tree mortality models. For. Ecol. Manage. 141, 271-284. doi: 10.1016/S0378-1127(00)00335-2

Farquhar, G. D., O'Leary, M. H., and Berry, J. A. (1982). On the relationship between carbon isotope discrimination and the intercellular carbon dioxide concentration in leaves. Aust. J. Plant Physiol. 9, 121-137.

Ferretti, M., Nicolas, M., Bacaro, G., Brunialti, G., Calderisi, M., Croisé, L., et al. (2014). Plot-scale modeling to detect size, extent, and correlates of changes in tree defoliation in French high forests. For. Ecol. Manag. 311, 56-69. doi: 10.1016/j.foreco.2013.05.009

Flannigan, M. D., Stocks, B. J., and Wotton, B. M. (2000). Climate change and forest fires. Sci. Tot. Environ. 262, 221-229. doi: 10.1016/S0048-9697(00)00524-6

Garcia-Forner, N., Sala, A., Biel, C., Savé, R., and Martinez-Vilalta, J. (2016). Individual traits as determinants of time to death under extreme drought in Pinus sylvestris L. Tree Physiol. 36, 1196-1209. doi: 10.1093/treephys/tpw040

Gower, S. T., Kucharik, C. J., and Norman, J. M. (1999). Direct and indirect estimation of leaf area index, fAPAR, and net primary production of terrestrial ecosystems. Remote Sens. Environ. 70, 29-25. doi: 10.1016/S0034-4257(99)00056-5

Grote, R., Gessler, A., Hommel, R., Poschenrieder, W., and Priesack, E. (2016). Importance of tree height and social position for drought-related stress on tree growth and mortality. Trees 30, 1467-1482. doi: 10.1007/s00468-016-1446-x

He, Q., and Bertness, M. D. (2014). Extreme stresses, niches, and positive species interactions along stress gradients. Ecology 95, 1437-1443. doi: 10.1890/13-2226.1

Janhäll, S. (2015). Review on urban vegetation and particle air pollution. Deposition and dispersion. Atmos. Environ. 105, 130-137. doi: 10.1016/j.atmosenv.2015.01.052

Jucker, T., Bouriaud, O., Avacaritei, D., and Coomes, D. A. (2014). Stabilizing effects of diversity on aboveground wood production in forest ecosystems: linking patterns and processes. Ecol. Lett. 17, 1560-1569. doi: 10.1111/ele.12382

Liang, J., Crowther, T. W., Picard, N., Wiser, S., Zhou, M., Alberti, G., et al. (2016). Positive biodiversity-productivity relationship predominant in global forests. Science 354:aaf8957. doi: 10.1126/science.aaf8957

Liu, D., Ogaya, R., Barbeta, A., Yang, X., and Penuelas, J. (2015). Contrasting impacts of continuous moderate drought and episodic severe droughts on the aboveground-biomass increment and litterfall of three coexisting Mediterranean woody species. Glob. Chang. Biol. 21, 4196-4209. doi: $10.1111 /$ gcb.13029

Lloret, F., Keeling, E. G., and Sala, A. (2011). Components of tree resilience: effects of successive low-growth episodes in old ponderosa pine forests. OIKOS 120, 1909-1920. doi: 10.1111/j.1600-0706.2011.19372.x

McKinley, D. C., Miller-Rushing, A. J., Ballard, H. L., Bonney, R., Brown, H., CookPatton, S. C., et al. (2017). Citizen science can improve conservation science, natural resource management, and environmental protection. Biol. Conserv. 208, 15-28. doi: 10.1016/j.biocon.2016.05.015

Michel, A., and Seidling, W. (eds.). (2014). Forest Condition in Europe: 2014 Technical Report of ICP Forests. Report under the UNECE Convention on Long-Range Transboundary Air Pollution (CLRTAP) (BFW Austrian Research Centre for Forests), BFW-Dokumentation 18/2014.

Millar, C. I., and Stephenson, N. L. (2015). Temperate forest health in an era of emerging megadisturbance. Science 349, 823-826. doi: 10.1126/science.aaa9933

Park, A., and Cameron, J. L. (2008). The influence of canopy traits on throughfall and stemflow in five tropical trees growing in a Panamanian plantation. For. Ecol. Manage. 225, 1915-1925. doi: 10.1016/j.foreco.2007.12.025 
Perry, J. A., Troelstrup, N. H. Jr. (1988). Whole ecosystem manipulation: a productive avenue for test system research? Environ. Toxicol. Chem. 7, 941-951. doi: 10.1002/etc.5620071111

Rigling, A., Bigler, C., Eilmann, B., Feldmeyer-Christe, E., Gimmi, U., Ginzler, C., et al. (2013). Driving factors of a vegetation shift from Scots pine to pubescent oak in dry Alpine forests. Glob. Change Biol. 19, 229-240. doi: $10.1111 /$ gcb. 12038

Ruiz-Benito, P., Lines, E. R., Gómez-Aparicio, L., Zavala, M. A., and Coomes, D. A. (2013). Patterns and drivers of tree mortality in iberian forests: climatic effects are modified by competition. PLoS ONE 8:e56843. doi: 10.1371/journal.pone.0056843

Sánchez-Salguero, R., Navarro-Cerrillo, R. M., Swetnam, T. W., and Zavala, M. A. (2012). Is drought the main decline factor at the rear edge of Europe? The case of southern Iberian pine plantations. For. Ecol. Manag. 271, 158-169. doi: 10.1016/j.foreco.2012.01.040

Savolainen, O., Pyhäjärvi, T., and Knürr, T. (2007). Gene flow and local adaptation in trees. Ann. Rev. Ecol. Evol. Syst. 38, 595-619. doi: 10.1146/annurev.ecolsys.38.091206.095646

Timmermann, V., Potočić, N., Sanders, T., Trotzer, S., and Seidling, W. (2016). "Tree crown condition and damage causes," in Forest Condition in Europe: 2016 Technical Report of ICP Forests. Report under the UNECE Convention on Long-Range Transboundary Air Pollution (CLRTAP), eds. A. Michel and W. Seidling (Vienna: BFW Austrian Research Centre for Forests), 20-58. BFWDokumentation 23/2016.

Van Gunst, K. J., Weisberg, P. J., Yang, J., and Fan, Y. (2016). Do denser forests have greater risk of tree mortality: a remote sensing analysis of density-dependent forest mortality. For. Ecol. Manage. 359, 19-32. doi: 10.1016/j.foreco.2015.09.032
Van Leeuwen, E. P., Hendriks, K. C. M. A., Klap, J., De Vries, W., and De Jong, E., Erisman, J. W. (2000). Effects of environmental stress on forest crown condition in Europe. Part II: estimation of stress induced by meteorology and air pollutants. Wat. Air. Soil Pollut. 119, 335-362. doi: 10.1023/A:10051822 26292

von Gadow, K., Zhao, X. H., Tewari, V. P., Zhang, C. Y., Kumar, A., Corral Rivas, J. J., et al. (2016). Forest observational studies: an alternative to designed experiments. Eur. J. For. Res. 135, 417-431. doi: 10.1007/s10342-0160952-0

Wermelinger, B., Rigling, A., Schneider Mathis, D., and Dobbertin, M. (2007). Assessing the role of bark- and wood-boring insects in the decline of Scots pine (Pinus sylvestris) in the Swiss Rhone valley. Ecol. Entomol. 33, 239-249. doi: 10.1111/j.1365-2311.2007.00960.x

Yan, H., Wang, S. Q., Billesbach, D., Oechel, W., Zhang, J. H., Meyers, T., et al. (2012). Global estimation of evapotranspiration using a leaf area index-based surface energy and water balance model. Remote Sens. Environ. 124, 581-595. doi: 10.1016/j.rse.2012.06.004

Conflict of Interest Statement: The authors declare that the research was conducted in the absence of any commercial or financial relationships that could be construed as a potential conflict of interest.

Copyright $(02017$ Bussotti and Pollastrini. This is an open-access article distributed under the terms of the Creative Commons Attribution License (CC BY). The use, distribution or reproduction in other forums is permitted, provided the original author(s) or licensor are credited and that the original publication in this journal is cited, in accordance with accepted academic practice. No use, distribution or reproduction is permitted which does not comply with these terms. 